\title{
Companion Pieces Written Through a Drift
}

\author{
Lesley Stern \& Kathleen Stewart
}

These pieces began with a writing experiment. We participated in a conference called Ex-Situ organized by Craig Campbell and Yoke-Sum Wong at the University of Texas in April 2014. The conference began with a workshop of paper presentations in Austin. Then thirty or so people traveled by car to Marfa in West Texas, writing along the way. In Marfa there was a second workshop presenting the works that had come together on the trip out. The journeys out and back ranged from 3 to 5 days. The two authors of this writing traveled together. Here we present two companion pieces written during and after our trip together.

Craig and Yoke-Sum called us together around the concept of ex situ with writing such as this (excerpted from the flyer for the workshop):

The concept of being ex-situ seems to hold the potential for us to move on a different register. It is a very common situation we find ourselves in as mobile bodies in this world: from Paris to Kyzyl to Marfa to Edmonton. Ex-situ doesn't raise a hierarchy but through travel and displacement, perhaps, it finds appeal in site-specificity, in the terror of knowledge and ideas; 'here' might take us 'there' or 'everywhere'. Taking account of resonance and echo, the situatedness of place/site encompasses connecting experiences. Ex-situ plays upon those connections, contingencies, convergences, correspondences, layers - material, emotional and mnemonic. 
In this piece, then, we are describing the thick entanglement of subjects and objects, aesthetics and politics, as something that happens on the register of affects. Travelling across a vibrant landscape with each other and others, and armed with the task of writing, we were transported to a register in which 'things' of all kinds affect one another and are affected.

\section{The Lion, the Rooster and the Ferrari}

\section{Lesley Stern}

Marathon, Texas. It is early morning and light is creeping into the motel room. Last night we walked back to the motel under a huge black sky, so black the stars shone like the burnished feathers of a silver rooster, burros brayed, flights of angels winging us to our rest. I remember living in San Agustín Etla near Oaxaca, being kept awake and woken and harassed all day and night by the sound of braying burros, turkeys, a rooster, dogs, people. Gracias a los burros my rooster does not have to crow. He stands on the dressing table in front of a mirror so there are two of him. Sculptural. Silent. He is double and a doubler. He doubles the odds-of detouring discovery. I open the door and step out into the dusty parking lot. The sky is now a soft donkey grey, fringed to the east with vermilion, redness seeps out of the earth, filtering into the sky.

I can stretch my arm in any direction and reach the edge of solidity and then my fingers will close around the sky.

I take the rooster outside and photograph him. He is immobile. His coxcomb is scarlet, his body painted in swathes of yellow, green and blue. His tail is feathery, the featheriness of sliced tin, a shiny indigo blue. He is perfectly proportioned. His toes are splayed giving him a firm purchase on the ground, or the dressing table, or wherever he alights. Always out of place, he will be my register of place as we travel through desert regions towards Marfa.

The rooster joined us before the desert. In Johnson City, home of LBJ we find somewhere to pee: a tiny coffee shop in a large yard filled with ironware. Flying pigs and alligators and cows. All painted. On the counter a faded photo of a Starbucks van, the side door slid open so that 'tarb' is eliminated. What you see then is the Starbucks icon and the word 'sucks.' 
While he fixed me an excellent espresso, John and I swapped a few minimally anecdotal details-he'd lived in San Francisco, he could tell I wasn't from Texas. Probably not from San Francisco either. The old guy he's swapping yarns with, toothless, dusty, feels like he's roamed the local block for years, and probably drunk every bottle in town, but who knows? Who knows peoples' stories unless you drive with them for days and days through the desert and can talk of this and that and failed relationships and swap another hilarious story of another disastrous episode in the life of love. I asked John who made the rooster and the other creatures, where they came from. He looked at me quizzically as if to say which leg can I pull, which story will she buy, or as if he were asking himself is this a trick question, what's she after, this foreigner, who on this wide Earth wants to know about the provenance of painted tin tchotchkes, who gives a flying fuck where the rooster comes from. Then he laughs and says Juan, Carlos, Roberto, Ricardo, Miguel... an army of anonymous Mexicans. I realize then it was indeed a sneaky question, the sort of question that a snooty gardener asks, either to elevate her purchase, raise it out of the realm of tourist art and into the realm of artisanal individuality, or simply to trip up a pretentious vendor.

I could go back to Old Town in San Diego and buy this rooster, closer to the source of its production. Or just nip across the border and buy it by the side of the road. Probably I could even nip back to Zimbabwe and buy the same rooster.

And yet not exactly the same.

There was a bigger rooster, grander. But as soon as my eyes lit upon this one I knew he was the one for me. He is life size, perfectly proportioned, he has stepped out from a child's picture book, from meticulously illustrated Mexican playing cards. R for rooster, $G$ for gallo. Watch out, says the old guy, he's a cantankerous rooster, that one.

Molly, who has turned up at the bakery with Allen and Lynsey, says we will photograph the rooster everywhere we stop on our journey towards Marfa. He will be our sign, our register of place. The problem is Molly drives off with her lovely camera and I only have a phone. Luckily, the rooster responds well to iPhone attention. Preens, holds still while I teeter and shake.

In Harper, where we get gas, he stands beneath a wall on which is painted a much larger than life US flag and under it a large star of David and the slogan: Stand By Israel. Over the doorway on the same wall it 
says Building for Sale. Somehow my focus is screwy and the rooster is cut out of the picture.

He does appear, albeit tinily at the bottom of the frame, under two bucking broncos, at Lowe's a local market in Fort Stockton. We had a cup of tea at a restaurant here and the young Mexican American who served us wouldn't take any payment; it's just water he said. I bought a bar of fancy dark chocolate with sea salt, an anomalous foreign import, and Katie bought a local newspaper. We ate the chocolate at the Rock House by the Rio Grande. It was musty.

In Marathon we have breakfast at Nancy's Coffee Shop. Under the large sign is scrawled, faintly, barely legible, 'Foiled Again.' He stands in the large expanse of the dirt parking lot in front of our rooms. The horizon is so low it just peeks over his head.

We drive down into Big Bend National Park. At last and eventually we arrive at Terlingua ghost town. There is a row of seats along the verandah of the saloon that is also a gift shop and also the hotel, next door to the Starlight Theatre and Bar which only opens at $5 \mathrm{pm}$ so we will not get there, but it looks enticing, stars are painted on the ceiling. On the verandah everyone has a bottle in hand, slow gossip fuels the atmosphere. New people in town, everyone is alert but pretends to notice nothing. Though they all noticed Norah. Someone has already picked up the keys to the Rock House, and when I ask who she says a boy and a girl with tattoos. Norah later tells us that on her way out a woman grabs her arm to comment on her tattoos and confides loudly that she has her ex-boyfriend's name tattooed on her butt.

At the Rock House the Rooster sits on a table, the Rio Grande behind him. And then I bring him in for the night to sit safely at the foot of my bed. There are rooster thieves abroad, and vigilance is required. The next morning as we drive away we see Mexican cowboys on their horses fixing the fence. What a way, I think, to fix the border. But Katie says there is no fence here, the river serves as the border between countries, the cowboys are just looking out for their cattle that do not know to not cross the Rio Grande.

We reach Marfa, the rooster and I. You would not exactly call him Juddesque, my rooster. Picturesque, yes. Ex-situ incarnate. 
And then we leave Marfa. As the desert spreads out behind us the radio crackles into coherence. The rooster sits silently in the back seat of the car, but the air around him is volatile, and even though the car appears and feels to us like an airtight razor sharp capsule slicing through space, something escapes, the rooster's colors vibrate, charging the landscape, inviting reciprocal attention. A doubler, he is an attraction and he attracts, he elicits color, winkling out of desert hues streaks and swathes and seas of vivid primary color.

All along the highway on the plateau before the western edge of the Texas Hill Country we listen to country music, all along the highway where wildflowers bloom: swathes of bluebonnets intermingled with red and yellow.

We stop for lunch in Ozona, a small big town, the county seat of Crockett County, named for Colonel Davy Crockett, a hero of the Alamo. We drive through the town looking for a steak house Katie once ate at and remembers hungrily but it is nowhere to be found. The streets of the town are deserted on this Sunday, faded tatty shuttered shops are strung along the main street fanning out from the civic center-gracious and impressive buildings, solidly built of stone. The Café Next Door is the only non fast-food place we can find off the freeway. We expect it to be full of travelers like ourselves, but it is chock-a-block with families out for Sunday lunch, dressed up a little, probably coming here after church. The little girls have colored bows in their hair, some of the men wear clean and crisply bright red shirts, with black jeans and skinny black ties and polished boots and Texan hats. People are eating big, but we delicate and discerning city girls order toasted cheese and salad. The sandwich has been heated, but the cheese resists melting, its plasticity and psychedelic orange hue pronounced by heat. We don't say anything to one another, we are hungry and wolf the sandwich down. But later, as we drive through an expanse of nowhere Katie, says, out of the blue, 'That cheese was scary.'

In the town of Frederiksburg, with its lovely stone buildings that seem to have been eerily transported from an earlier and European era, we are again craving tea and so return to the Old German Bakery and Restaurant. On the way out to Big Bend and Marfa we had delicious bratwurst and sauerkraut here and a pork cutlet that was even better cold the next morning in the motel at Marathon watching the sun come up. Over the blackboard menu in the Bakery there was a montage of 
photos, some showing a part of the town invisible to a passer-through: faded walls, deserted streets, graffiti; other photos and cuttings showed cavalcades, monuments, and John Kennedy's face cut from a German newspaper. The rooster had posed outside the bakery and Molly photographed him. He will not appear in the Bakery's montage and I have never seen Molly's photograph, but I have a vivid image of him there, casually consecrating the site.

The bakery is closed this Sunday, so we wander round a back street and Katie shows me the Sunday houses and tells of how she stayed there with her mother and father when they were both still alive. These are small weekend houses that the ranchers and farmers built in the late 1800 so that they could spend a night or two when they came in to town for church and perhaps to party. They are small houses, craft houses meticulously constructed out of local materials, now mostly rented out to tourists. Katie's voice softens as she tells me about these houses.

We find a cup of tea at a Biergarten where two young girls in their sparkling twenties are taking their grandparents out for dinner or lunch in this Sunday mid-afternoon, and have to shout a lot, and at the table next to us, a party of retirees, just off the coach, are checking out the town on their iPhones, comparing maps and statistics.

North of Frederiksburg we pull in to a wildflower nursery, and walk through fields of blue, fields of red, whole fields like oceans, like we are swimming through a diaphanous red sea, light as air. Yoke Sum, in Marfa, had shown us the seed packets she and Derek had purchased here. She is going to take them back to England to plant in her garden, where, if the bluebonnets grow, they will become exotic rather than native. Here, although native, they did not sprout spontaneously along the highway. It was Lady Bird Johnson who was largely responsible for getting rid of the junkyards and billboards that graced the highway system, replacing them with native plantings, through her support for the Beautification Act of 1965. Before this road trip if you had tossed to me the words Johnson and 1965, and asked me to say whatever came into my mind I would have said Vietnam, napalm, and the Civil Rights Act of the previous year. That word, beautification, it slightly churns the stomach and curls the lip. Botox and pansies, landscaping and real estate, Sunday best, veneering.

Yet Lady Bird Johnson's legacy lives on, particularly in the infelicitously and far-from-beautifully named Surface Transportation and Uniform Relocation Assistance Act of 1987, which requires that at least 0.25 of 1 
percent of funds expended for landscaping projects in the highway system be used to plant native flowers, plants and trees. As we swim through the crimson air of the poppy meadows in the flower fields I ponder the shiftiness of that word beautification, the slipperiness of terms like native and exotic, the chimerical propensity of color and how it can be strangely conjured into being through political process and the enactment of policy, but also strangely through the agency of objects charged with magical propensity.

I board the plane in Austin, bound for home, buckle up, and with eyes closed hear again the night train in Marathon. Movie fragments, night sounds, flicker across the screen of memory: the central Australian desert in Night Cries, black-and-white images in Killer of Sheep. That wailing sound rises, from somewhere within, then fades across the surface of my skin. It feels like the after-purring of a large cat, when growling segues into purring, and purring slowly ripples into soundlessness, until all that remains is a somatic memory.

On the runway all of a sudden lightning streaks across the darkening sky and hailstones start falling. The wing of the airplane is soon covered in whiteness. A shiver shoots through the plane, there is a quivering in the air. We prepare to disembark but then the crisis subsides as quickly as it erupted, the sky clears, the mood shifts. Sparks of electricity remain in the atmosphere, however, people start talking, there's an expansiveness that wasn't there before. I am sitting next to a young woman who endears herself to me by showing concern for the rooster who, in his overhead bin, has been jostled by a bag stuffed in haphazardly by a rough and rude young man. She tells me that her mum collects roosters and even has some from Soviet-era Russia. I'm not really a collector, I demur. I can understand that, she says, he is clearly the one and only.

My surly hermeticism is instantly vanquished, the conviviality of airplane small talk sucks me into its orbit. Maria tells me that she volunteers as an animal rescuer, fostering creatures from the wild so that they can eventually be returned to something like a natural state. As a student she worked at the Austin Zoo and Animal Sanctuary. Occupying a large acreage in the hill country, this zoo is home to many domestic and exotic animals that were either rescued from, or unwanted by, their owners. 
Toads are rescued, goats, donkeys and snakes, but also coyotes, cougars, lions, tigers. All the big cats are endangered in their native habitat, and in quasi-legal captivity too, and so zoos often see themselves as places of preservation and restoration. A mode of domestic rewilding. Maria tells me a story about a lion. My jaw drops inch by inch until it reaches the floor and a great gaping hole opens up in my stomach.

The story Maria tells me goes like this. A lion was rescued from a church. Used in religious theater he would be wheeled onto the stage with a lamb. He had been drugged out of his mind, overfed and malnourished, confined to a small cage in a trailer, never exercised. When he was released and stepped on to the ground for the first time he buckled under his own weight. All the bones in his feet shattered.

Later I will find on the Internet a photo of a blonde man, a pastor as it turns out, in a pink jacket, open-necked shirt and khakis, clutching in his arms a lamb. He stands on a stage and you can see, behind him, a caged lion. Ed Young is a mega-church pastor, best-selling author and televangelist. The lion and the lamb were brought onto stage as part of his Wild Sermon series. He is often described as creative, is a flamboyant performer, in his services he deploys props, gimmicks, visual theater. $\mathrm{He}$ is prone to putting into play everyday sayings and of dramatizing biblical metaphors through literalization and embodiment.

The lion, you might say, was simply a prop, a visual aid, an illustration of language. Functionally it was equivalent to the Ferrari which Ed Young drove onto the stage one Sunday as part of a sermon illustration for his series titled 'RPM: Relationships. Passion. Marriage.' 'God gave me a Ferrari,' Young said, 'because I am a Ferrari. You're a Ferrari too. God has given you a Ferrari.' The Ferrari it seems is the body, and at the same time you are a Ferrari because you are made in the image of God.

Maria told me that there is a happy end to the story, they eventually managed to rehabilitate the lion, and in the zoo he can roam, as though in the wild. I cannot say with certainty that Maria's lion is the same lion that Ed Young brought onto the stage. There was a flurry, a media exposé, but a spokesman for the Fellowship Church says the lion was back 'at home' on his California reserve where he has thousands of acres on which to roam. No permits were requested for the theatrical sermon because none were needed. No prosecutions ensued. The lion, in the media and Internet coverage, simply disappeared into some mythical Californian savannah, or into thin air. 
The lion and the Ferrari. Each a thing, a prop, a visual aid, a charged image. Or perhaps they are objects charged with magical propensity. They are things, albeit different sorts of things, yet transformed from thingness through embodiment and rhetorical sleight of hand. The theatricality of the symbolic dimension. And the rooster, my rooster? Is he a thing, a prop, a visual aid? What sort of a thing is he?

The wailing of the train and the roaring of the lion.

I shall take him home this rooster, a Texan I guess, home to California where he will be charged to remember all the fantastical details of this journey which I shall forget slowly, memory by memory.

\section{Things that Shine}

\section{Kathleen Stewart}

Lesley and I are participating in an experimental workshop, Ex-Situ. There is first a day-long workshop in Austin where, in accordance with the experiment, people give papers in a fairly standard academic atmosphere. Those presenting have already been charged with the spirit of experiment so there is some friction between individual papers and members of the audience. There are even some semi-accusations hurled as the critics follow along with the papers but come across sticking points. Are we going too far, are we letting out secrets, is it ok to be a little snarky about your ethnographic subjects? The tone of the room wants to play and does become playful, but also, in that very shift, it tries to lurch back to the land of the serious, responsible, even a sanctimonious counterbalance. We learn things about academia through a sensory encounter. There are also objects floating around the room and taking off. Partially deflated and yet also energized critiques are flopping around with a question of something magically mundane or some question of the real. The edges of both the objects and the critiques are fluffing up with attitude projected or spied. There are questions of allegiance. 
The next day we're on the road. Right away things are not just calmer but peaceful. The light is slightly miraculous. Suddenly I am remembering my life along the trail through Johnson City and beyond. Corporeal memories are popping into view with a tree on the side of the road, a picnic area where we stopped several times, an ornate Victorian county courthouse, the ruined grain mill that had been a utopian artists' colony. We had visited the artists' colony over the years. Even twenty years ago already in an early state of ruin, we had visited the different stages of its decay as its slow passing following suit of the building itself and its initial industry. At one time, the artists' colony had occupied a dozen crafts shops specializing in woodwork, welding, or candle-making. The first time we visited, now twenty years ago, the shops were abandoned and left open to the dust, the wind, and visitors. I remember that one of them had ancient shoes nailed all over the walls. There were also the remains of a carousel and bits of a miniature train extending out across a creek and into a field on the other side. The grain elevator itself was covered with gigantic sculptures of working men climbing its sides with tools in their hands. There was some reference to the Wobblies. There was an active theatre in the mill and a barbeque restaurant whose walls were covered, every inch, with neon beer signs and plaques embodying old West sayings, jokes about marriage, and declarations of war or loyalty. I can't remember now what they said but I remember the overwhelming sensory immersion in them when you walked in the door. Now the theatre and the restaurant are gone, sending my memories skidding over different times with different people, most of them now gone too.

Impeckable Aviaries is still in the old storefront in Johnson City. It is, as usual, closed to walk-in business. There are bird cries behind the fence on the side. You can peer through the cracks into an overgrown bamboo paradise, looking for the giant Victorian birdcages that, it seems to me, used to be visible. It seems as though I used to see the birds there though I don't really know what Double Yellow-Headed and Lilac-Crowned Amazons look like. If I saw them, I have no clear residual visual image. But I still feel the presence of the encounter with them.

It has been years since I've wanted to buy something sentimental. But I am put on pause while Lesley shops for a rooster. She's intent; she's established a line of inquiry for herself, a search. I am inspired by her. So rather than just wait I make a decision to actively drift. I go into a cabin with a sign I find obnoxious in its aim at some cowboy-gesturing Western 
tourist man: 'This cabin for sale. 21k. Pick it up and haul it away. Sleep when you die.' I ignore this sign, practically covering my eyes from its very sight. Yet as I step into the cabin I suddenly remember a shopping smell from twenty-five years ago. The memory sensation is set off by a dusty-homey smell of the prairie old West tempered by a sweet-home Texas smell. The smell is coming from a large antique wooden dresser sitting still in a corner. I stand in the middle of the cabin staring at it and then slowly let my eyes wander over the other things collected in this cabinet of curiosities. Then I stare again at the dresser. Stray fantasy questions drift through me, until I have exhausted this little tendril of shopping for an object to capture a past partly mine but also always already saturated with outside influences. I wonder, half-heartedly, how I would transport the dresser, where it would go in my house, what would have to go to make room for it, where I have seen a dresser like this before. In my grandmother's house, I think. But it also seems to me I must have had one of my own that was very much like it. Bits and pieces of things slide in and out of my head: other trips, other encounters with dressers, bedrooms with flowered wallpaper, iron beds, and thin curtains that blow in the breeze of opened windows. There are images from movies and photographs and stories tangled with some kind of experiences I had or must have had. Or it's as if I had them. Everything is tinted together. The stillness settles. I'm touching the Western lamps, thinking of my mother's lamps and the one Justin, my nephew transplanted to Montana, made in the manner of her. That one, a Western lamp too but Montana made, sits in my living room. I see a cast-iron picture frame with curlicues on the top. What sells me is the way the little frame swings on two little arms. It was a mistake, it was wrong of me, not to buy it and bring it along. I might not have taken pictures of it in places we stopped the way Lesley did with her rooster, but maybe I would have squirrelled it away in the trunk, secretly opening its imaginary brown wrapping paper to look at it from time to time.

By the time we get to Fredricksburg I'm pulling our convoy down side streets sparking on the little German Sunday Houses I stayed in years ago with my mother and father, my mother and sister, my mother, and before that some grad students from UT I didn't know very well and I can't even remember who they were. Each little house pops into view hauling into memory and sensation the (im)materiality of two days here, a night there, the stones we marveled over in the kitchen of that place, 
the flowers in old buckets on the porch there. There are still chairs on that porch. The images meeting memories create a pause in me, a suspension poised between the pleasure of the moment then and the (now realized) end that was coming.

By now I'm noticing the mugs with names on them in the Old German Bakery, the dishwasher-wanted sign. I have a picto-fantasy of dropping into a little place like this for a few weeks and becoming simple. A place where a person would have something to do that's out and about with others. An 'as if' world. As if you don't have other things happening in your head or to your body or your life. As if things wouldn't get complicated, people wouldn't be hurtful or needy, you wouldn't get tired of it all. As if you wouldn't actually be on the ground in the middle of things that push and pull, excite and drain. Lesley cheerfully pulls me out this zone. She says we may have to walk off the lunch. But then I skid back on a new track. I picture an experiment of setting off to walk to Marfa. Let's say just for four hours, see how far we would get, see what would happen. Not far. Someone would have to pick us up. I think I say something to this effect but it's not a statement fully in the world and people look at me strangely, my half-articulation sitting awkwardly between us like an alien visitor we don't know what to do with.

Allen, Molly, and Lindsey keep showing up right behind us. It's like we're on a giant rubber band. We pull apart, even for hours, but as we home in on a destination they're back on our tail. There's some texting to coordinate but it's always beside the point, unnecessary, unwittingly after the fact; I'm still typing even as the actual people are already walking up the sidewalk on their own. Such a pleasure of unexpected efficiency. Somehow we are on one another like glue, but not stuck.

Lesley and I enter the desert - the West arrives in a proper form. We are already talking about failed relationships. The stories are long and dense, magnetizing people and times and mysterious desires or compulsions or something. We don't know exactly what drove the immersions into these worlds that were us for a while. These unfolding worlds get interrupted by scenes spied, vistas registered, stops for food, gas, pictures of the rooster, encounters with local people or other drivers engaged in expressivities of their own - 'Don't say anything to him, Katie, people shoot each other out here.' We enter a happy rhythm of deep story drenched in unpredictable detail interrupted by a propulsion into some kind of action and then back into the stories eagerly taking up where we left off. 
Each of us remembers where we were in the other's story - 'Ok, so what happened to the guy with the drugs?' The talk has vistas of far off places and long-gone lives that now overwrite the wide desert vistas around us. Everything has become literally amazing. The amazing scenery. The amazing situations we once found ourselves in and lived out. Things that now seem insane and so completely unlikely.

By the time we get to Marathon for the first night's stop we have magnetized a thick and popping collection of characters, scenes and events to a composition hitting notes between us. The sky opens into a surround-scene theatre of brilliant color and then a blanket of blackness filled with stars. We are not moving anymore. We are in silence. We walk into town, buoyed by the magically astonishing sounds of trains passing close by, burros braying and whinnying and frog croaks so deep and loud we have to stop to wonder what kind of creature that could be. To just listen. At the Gage Hotel, well-heeled Texans gather on a vast open patio for margaritas laced with cactus and jalapeños and bison steaks.

In the morning I set off early, alone, to get the lay of the land. I come across a mural of an alien on an old fence around a dusty house where things seem to be spilling out of windows and doors. I think there is something funny strange about the intersection of the UFO dream bubble of the 1990 s with the emergent monster of hoarding. It's as if this little spot in the desert is an extreme contact point where the wild trajectories of times gather and leave their mark. The scene attunes me to other scattered signs of intensities here: a gray-haired, three-legged, skinny dog (or coyote?) roaming just on the perimeter, plastic bags blowing down the dusty streets, spectacularly old trucks in beautiful faded pastels, an ugly beat up car with an open gas cap. I stop at the ancient gas station on the outskirts of town. I'm not sure it's open but the door is unlocked. I have to figure out how to use the pump, which is from before my time. Then I have to find the owner to pay. He's very calm. Grease covers the walls and the used parts scattered across the shelves. There is water for sale and beer. There are old calendars. A truck coming out of Big Bend stops to get gas for the trip back to Houston. An older, very fit, couple get out and starts to crawl over the gear and kayaks in the open bed of the truck, tying things down for the highway. Everything is covered in dust - backpacks, skin, picks, tents, water and oil jugs. These two are post-wilderness. Blissed out and sunk deep into some kind of happiness. We talk a little about what they've been doing - rivers and mountains, 
a cougar. I try to suss out who they are and what they're thinking. Then I go back to the Marathon Motel perched on the edge of the world to meet Lesley and go to a charmed breakfast place where we eat the best French toast I've ever imagined on thick white plates and someone plays a guitar on the porch.

We spend the day driving the length of Big Bend, stopping on trails to hike and at overlooks to eat sardines and slices of bread. For a stretch of time we end up behind a slow driver. Very slow. I say I can't even figure out how he exists. He sees us right behind him but it doesn't register. At all. He's chewing gum, he's talking to someone in the passenger seat, he's casually turning his head side to side, checking out what's happening. Talk about blasé. Lesley gets agitated, I think because she thinks I'm agitated - 'Get around him. Flash your lights at him'. But by now I'm on an even keel. Though still dumfounded by his.

I am under a spell I remember from earlier trips out here. It comes from the driving pace of co-witnessing incarnations of half-natural, half-human worlds. It starts at the sudden, inexplicable entrance to the desert on the other side of Fredricksburg and then sets in bodies in the hour-after-hour of the desert's unfolding. A nothingness in which things nevertheless keep appearing creates a fullness that swells to fill the container of the mind in the scenery like jello in a mold. It was on hour six of my first trip that I found the cowboy restaurant and bar in Ozona. A long wooden building filled with smoke and men eating fantastic steaks and baked potatoes. On the other side of the long wooden bar inside, men in cowboy hats drank whiskey and played poker. It was an ecology I could just see the outlines of. The place sang.

By the time we get to Terlingua we are windswept and acclimated to a wildly animated world. Our thinking is piecemeal and saturated. Our impressions are not just our own but the result of things coming in and out of phase, of objects impinging on another one. So Terlingua's ghost town displayed in all of its excess and the dusty people sitting on the long wooden covered sidewalk, drinking beer and watching us arrive as if we, too, are a breaking story, is just too much for me. They want to talk, they seem to be covered with tattoos and sayings. I have to shade my eyes. I keep walking to find a bathroom, get the key to The Rock House, and get out of there. Twenty miles down the road, The Rock House is a sudden mirage on the Rio Grande. Joey, Nora, Alejandro and Daniel are drinking rum and coke on the expanse of a patio 
overlooking Mexico. It is stunning and still. We sleep under the stars in the remains of a trading post.

The next morning is a rude awakening. By now the packing is in a shambles; we are throwing stray shoes and sweatshirts, bags of nuts, and bottles of half-drunk water into the car. We are due to present in Marfa. We drive the winding road that follows the river and then north, interrupted only by the dramas of crossing a zingy shockingly hyper-official very white border checkpoint, though we have never left the country. Our cellphones keep telling us welcome back to the United States.

In Marfa the Hotel Paisano is surprisingly gracious with high ceilings and arched doorways. Blue Mexican tile throughout carries a color shine across the lobby and into the open courtyard on one side and the ornate pool grotto on the other. The film crew and stars had lived at the hotel in 1955 while filming Giant. The grand entrances to the hotel are lined with film posters. In keeping with its status as a historical building, there are no elevators or phones in the hotel. You drag your things up a circular stairway and find your room by name. Mine is the Elizabeth Taylor room. It's massive and seems to have the original furniture from 1930. It has two bathrooms.

All over town there are signs of the artist Donald Judd's occupation of the town since the 1970s. The Chinati Foundation houses his permanent collections in a World War II army base just outside town. There are art galleries and modern art installations in old stone buildings and public squares. The conference gathers again in a beautiful book store supported by the artist colonies here now and the waves of art tourists that have joined the outdoor enthusiasts in the visiting zone. We have gourmet pizza brought in for lunch while we bleat out our stories and show and tell beautiful photographs and spoof film on Paris, Texas. One woman reveals maps of underground oil pipes covering every inch of Texas including the wild scenic territory we've just been through. She feeds us Rice Crispie treats so that we can feel the petroleum melting down our throats in the form of marshmallow. The bell of a wake-up call is ringing but I'm so far gone that it's just one more thing that shines.

The graduate students are happy. They gather, drinking free gourmet mixed drinks out of plastic cups from the foodie festival in the Paisano courtyard, at gigantic picnic tables under a shade cover the size of a stockyard on the railroad tracks in the middle of town. They run across the wide, cattle-steering street for pictures for their Tumblr assemblages. 
The next morning on our way out of town we have breakfast in a poor Mexican restaurant that barely feels like a public place. We gaze at men eating tripe. It's Sunday. We make our way back faster than we came, sticking to the highway except for a few forays into the few towns along the way trying to find again remembered things.

Back in Austin something of this trip stays with me for a while (and even now). Living and non-living things seem a little more poised on the verge of expression. Thought-feeling ventures into an incipiency. There is a sense of the as-if quality of things infused with the surprise of accruals, fractures, gestures and losses.

I am back to learning native plants one at a time. Digging dirt in the Edward's Plateau shallow limestone and caliche and the Blackland Prairie clay, I come to know Barberry, Arelia, Acanthus, Guava, Cast Iron plant, Red Columbine, Coreopsis, Firecracker Fern, Bearded Iris, Shrimpplant, Mexican Feathergrass, Texas Wisteria, and Monkey Grass.

One day I am raking leaves in the backyard when I hear loud honking and yelling on the street. Thinking one of our dogs or cats has gotten out (again), I run through the gate to find neighbors and pedestrians standing in the street yelling back and forth. 'What was that? We should call the police. Did you get her license plate?' A woman had been pushing a stroller with a dog attached. A car speeding up the street had nearly hit her and then stopped to yell 'GET OUT OF THE ROAD!!!' before screeching off. The woman of a young couple coming down the street from the other direction (also with a stroller) says the driver is well known as the crazy driver and there's a YouTube clip of her doing this kind of thing. She tells us how to find it online. The police have been called many times. Her license plate has been circulated on the neighborhood listserv. There's a pause. We look at each other. The scene feels over-filled with the tangled, ricocheting resonances of things but we're not quite sure what things exactly. The things that make people snap or that make people follow the crazy snappings of others online. The things that compose a neighborhood that watches. I wonder where the crazy woman lives, what it's like inside her house/life/car. My wonderings are shored up by the expectation scored into my senses and others' that things will happen, scenes will emerge that are partial revelations suddenly cut adrift in a landscape we move through. 